RESEARCH NOTE

\title{
Notes on reproduction of black toads from California
}

\author{
STEPHEN R. GOLDBERG*
}

Whittier College, Department of Biology, Whittier, CA 90608, USA

*Corresponding Author: sgoldberg@whittier.edu

Key words: Anaxyrus exsul, black toad, California, Deep Springs Valley, Inyo County, reproduction

The black toad, Anaxyrus exsul (Myers 1942), is a mainly diurnal species known only from marshes and springs feeding Deep Springs Lake, Deep Springs Valley $\left(37.333^{\circ} \mathrm{N}\right.$, $118.01759^{\circ} \mathrm{W}, 1,525 \mathrm{~m}$ elevation), Inyo County, California. The valley is enclosed between the White and Inyo Mountains (Dodd 2013). The entire natural range of $A$. exsul is limited to approximately 15 ha, one of the smallest ranges for any North American amphibian (Green et al. 2013). Because of this small distribution there is concern that an environmental catastrophe such as introduction of a disease or predator could result in the extinction of $A$. exsul (Green et al. 2013).

Information on A. exsul reproduction is limited. Anaxyrus exsul reproduction occurs in freshwater marshes and sloughs associated with Deep Springs Lake (Dodd 2013). Breeding of $A$. exsul occurs in the early spring, from late March to late April (Schuierer 1962; Kagarise Sherman 1980). Stebbins and McGinnis (2018) reported $A$. exsul breeding occurred from mid-March to May, perhaps as late as June; they are active in the fall until November (Dodd 2013). Anaxyrus exsul is rated critically imperiled (G1) by NatureServe Explorer (2019), state threatened in the California Natural Diversity Database (CNDDB 2019) and vulnerable by Hammerson (2004). In this paper, I provide additional information on the reproductive cycle of $A$. exsul from an examination of museum specimens. The values for minimum sizes for males and females at maturity, based on histological examination, may be valuable in efforts to reestablish or maintain populations of $A$. exsul. The use of museum collections for obtaining reproductive data avoids euthanizing specimens and avoids the need for collecting permits from state and federal authorities.

I examined a sample of $22 \mathrm{~A}$. exsul from Inyo County, California collected 1954 to 1967 consisting of 15 adult males (mean snout-vent length, $\mathrm{SVL}=46.5 \mathrm{~mm} \pm 4.0 \mathrm{SD}$, range $=38-51 \mathrm{~mm}$ ) and seven adult females (mean $\mathrm{SVL}=50.7 \mathrm{~mm} \pm 2.3 \mathrm{SD}$, range $=48-53 \mathrm{~mm}$ ) from the herpetology collection of the Natural History Museum of Los Angeles County (LACM), Los Angeles, CA, USA.

I made a small incision in the lower part of the abdomen, removed the left testis from males and a piece of the left ovary from females, embedded them in paraffin, cut sections at $5 \mu \mathrm{m}$ and stained them with Harris hematoxylin followed by eosin counterstain (Presnell and Schreibman 1997). I deposited histology slides at LACM and tested for differences 
between adult male and female SVLs using an unpaired $t$-test (Instat, vers. 3.0b, Graphpad Software, San Diego, CA).

The testicular morphology of $A$. exsul is similar to that of other anurans as detailed in Ogielska and Bartmanska (2009a). Within the seminiferous tubules, spermiogenesis occurs in cysts which are closed until the late spermatid stage is reached; cysts then open and differentiating sperm reach the lumina of the seminiferous tubules (Ogielska and Bartmanska 2009a). All fifteen adult males in my sample exhibited spermiogenesis. By month these were: April $(\mathrm{N}=2)$, June $(\mathrm{N}=4)$, November $(\mathrm{N}=9)$. One June male (LACM 36676, SVL $=48 \mathrm{~mm}$ ) contained only small clusters of sperm in the seminiferous tubules, in comparison to the abundant sperm in the testes of the other males. Because of the presence of sperm, I considered this male to be an adult, although it is not known if it would have successfully mated. The smallest mature $A$. exsul males exhibiting full spermiogenesis measured $38 \mathrm{~mm}$ SVL (LACM 26128, 26144) and were from November. Wright and Wright (1933) measured body sizes (body length) from the tip of the snout to the rear end of the body back of the vent, (equivalent to SVL), and reported adult males of $A$. exsul ranged from 44 to $59 \mathrm{~mm}$ in body length. The smaller value for male maturity of $A$. exsul reported herein may by the result of my histological examination of the testes which was not done by Wright and Wright (1933).

The mean SVL of $A$. exsul females was significantly larger than that of males $(t=2.6$, $d f=20, P=0.017)$. The ovaries of $A$. exsul are similar to those of other anurans in being paired organs lying on the ventral sides of the kidneys; in adults the ovaries are filled with diplotene oocytes in various stages of development (Ogielska and Bartmanska 2009b). Mature oocytes are filled with yolk droplets; the layer of surrounding follicular cells is thinly stretched. My female sample consisted of seven: two from April, three from June and two from November. All were in spawning condition in which mature oocytes predominated. Adult females of A. exsul ranged from 46 to $61.5 \mathrm{~mm}$ in body length (Wright and Wright 1933). The smallest mature $A$. exsul females (in spawning condition in my LACM sample both measured $48 \mathrm{~mm}$ SVL (LACM 26097, 26098) which is within the size range for adults of $A$. exsul in Wright and Wright (1933).

Atresia is a widespread process occurring in the ovaries of all vertebrates (Uribe Aranzábal, 2009). It is common in the amphibian ovary (Saidapur 1978) and is the spontaneous digestion of a diplotene oocyte by its own hypertrophied and phagocytic granulosa cells which invade the follicle and eventually degenerate after accumulating dark pigment (Ogielska and Bartmanska 2009b). See Saidapur and Nadkarni (1973) and Ogielska et al. (2010) for a detailed description of stages of atresia in the frog ovary. Atretic follicles were observed in $(100 \%, 7 / 7)$ of my $A$. exsul mature female sample. Atresia plays an important role in fecundity by influencing numbers of ovulated oocytes (Uribe Aranzábal 2011). Incidences of atresia increase late in the reproductive cycle when follicles that did not ovulate are resorbed (Saidapur 1978). Saved energy is presumably utilized in the next activity season. The causes of follicular atresia in nonmammalian vertebrates are not fully understood although it has been associated with captivity, food availability, crowding and irradiation (Saidapur 1978). In amphibians adverse environmental conditions such as starvation and suboptimal lighting may cause atresia of vitellogenic oocytes (Jørgensen 1992).

It is likely the two gravid $A$. exsul females from November would have kept their eggs until spring before spawning. This appears to be the case for Rana boylii (Goldberg 2019; Zweifel 1955) and Rana cascadae (Goldberg 2020), both from California, in which females from autumn with mature oocytes apparently delay spawning until spring. Jørgensen 
et al. (1979) reported that by the time of hibernation, ovaries are close to breeding size in frogs from the temperate zone. Therefore, it may be advantageous for $A$. exsul to be capable of spawning soon after emergence from hibernation rather than delaying reproduction to undergo a period of yolk deposition.

\section{ACKNOWLEDGMENTS}

I thank Gregory B. Pauly (LACM) for permission to examine $A$. exsul.

\section{LITERATURE CITED}

California Natural Diversity Database (CNDDB). 2019. State and federally listed endangered and threatened animals of California. California Department of Fish and Wildlife. Available from: www.wildlife.ca.gov (Accessed 3 October 2019).

Dodd, C. K., Jr. 2013. Frogs of the United States and Canada, Volume 1. Johns Hopkins University Press, Baltimore, MD, USA.

Goldberg, S. R. 2019. Notes on reproduction of the foothill yellow-legged frog, Rana boylii (Anura: Ranidae), from California. Sonoran Herpetologist 32:43-45.

Goldberg, S. R. 2020. Notes on reproduction of Cascades frogs from California. California Fish and Wildlife 106:215-219.

Green, D. M., L. A. Weir, G. S. Casper, and M. J. Lannoo. 2013. North American Amphibians Distribution and Diversity. University of California Press, Berkeley, CA, USA.

Hammerson, G. 2004. Anaxyrus exsul. The IUCN Red List of Threatened Species 2004. Available from: https://dx.doi.org/10.2305/IUCN.UK.2004.RLTS. T3169A9647112.en (Accessed: 26 March 2020).

Jørgensen, C. B. 1992. Growth and reproduction. Pages 439-466 in M.E. Feder and W.W. Burggren, editors. Environmental Physiology of the Amphibians. The University of Chicago Press, Chicago, IL, USA.

Jørgensen, C. B., L. O. Larsen, and B. Lofts. 1979. Annual cycles of fat bodies and gonads in the toad Bufo bufo bufo (L.), compared with cycles in other temperate zone anurans. Bilogiske Skrifter 22:1-37.

Kagarise Sherman, C. 1980. A comparison of the natural history and mating system of two anurans: Yosemite toads (Bufo canorus) and black toads (Bufo exsul). Dissertation, University of Michigan, Ann Arbor, MI, USA.

NatureServe Explorer. 2019. An online encyclopedia of life. Available from: explorer.natureserve.org (Accessed 3 October 2019).

Ogielska, M., and J. Bartmanska. 2009a. Spermatogenesis and male reproductive system in Amphibia-Anura. Pages 34-99 in M. Ogielska, editor. Reproduction of Amphibians. Science Publishers, Enfield, NH, USA.

Ogielska, M., and J. Bartmanska. 2009b. Oogenesis and female reproductive system in Amphibia-Anura. Pages 153-272 in M. Ogielska, editor. Reproduction of Amphibians. Science Publishers, Enfield, NH, USA.

Ogielska, M., B. Rozenblut, R. Augustynska and A. Kotusz. 2010. Degeneration of germ line cells in amphibian ovary. Acta Zoologica (Stockholm) 91:319-327.

Presnell, J. K., and M. P. Schreibman. 1997. Humason's animal tissue techniques. Fifth Edition. Johns Hopkins University Press, Baltimore, MD, USA. 
Saidapur, S. K. 1978. Follicular atresia in the ovaries of nonmammalian vertebrates. Pages 225-244 in G. H. Bourne, J. F. Danielli, and K. W. Jeon, editors. International Review of Cytology, Volume 54. Academic Press, New York, NY, USA.

Saidapur, S. K., and V. B. Nadkarni. 1973. Follicular atresia in the ovary of the frog Rana cyanophlyctis (Schneider). Acta Anatomica 86:559-564.

Schuierer, F. W. 1962. Remarks upon the natural history of Bufo exsul Myers, the endemic toad of Deep Springs Valley, Inyo County, California. Herpetologica 17:260-266.

Stebbins, R. C., and S. M. McGinnis. 2018. Peterson Field Guide to Western Reptiles and Amphibians. Fourth Edition. Houghton Mifflin Harcourt, Boston, MA, USA.

Uribe Aranzábal, M. C. 2009. Oogenesis and female reproductive system in AmphibiaUrodela. Pages 273-304 in M. Ogielska, editor. Reproduction of Amphibians. Science Publishers, Enfield, NH, USA.

Uribe Aranzábal, M. C. 2011. Hormones and the female reproductive system of amphibians. Pages 55-81 in D. O. Norris and K. H. Lopez, editors. Hormones and Reproduction of Vertebrates, Volume 2: Amphibians. Elsevier, Amsterdam, Netherlands.

Wright, A. H., and A. A. Wright. 1933 Handbook of Frogs and Toads of the United States and Canada. Comstock Publishing Associates, Ithaca, NY, USA.

Zweifel, R. G. 1955. Ecology, distribution, and systematics of frogs of the Rana boylei group. University of California Publications in Zoology 54:207-292.

Submitted 5 May 2020

Accepted 27 September 2020

Associate Editor was J. Olson

\section{APPENDIX}

Twenty-two A. exsul from Inyo County, California examined from the herpetology collection of the Natural History Museum of Los Angeles County (LACM), Los Angeles, California. LACM 26091, 26092, 26094, 26097, 26098, 26105, 26114, 26118, 26128, 26135, 26137, 26140, 26142, 26144, 26147, 26148, 26154, 26156, 26158, 36673, 36676, 87716. 